\title{
Prevalence and clinical specificity of fatigue symptoms in chronic fatigue syndrome, multiple sclerosis, and myasthenia gravis
}

This article provides a critical review of the psychological
and related literature on fatigue resulting in both mental
and physical experiences. On one hand, prolonged severe fa-
tigue is a prominent disabling symptom in various diseases
of different aetiology - psychiatric (e.g. depression), somatic
(e.g. some infections) and neurologic (e.g. multiple sclerosis,
myasthenia gravis). For instance, fatigue is a main symp-
tom of myasthenia that leads to pathological skeletal mus-
cle weakness. Furthermore, 40 to 90 per cent of individuals
suffering from multiple sclerosis confirm they have experi-
enced fatigue, which impairs their cognitive functioning. In
both multiple sclerosis and myasthenia, fatigue has not only
a physical but also a psychological dimension. On the other
hand, fatigue can be seen as an isolated set of symptoms of unknown origin called the chronic fatigue syndrome (CFS). The development of the concept, diagnostic criteria and some strategies of coping with CFS are presented. Various somatic disorders, as well as subjective cognitive and emotional complaints, are common and well documented in patients with CFS. The most typical include depression, as well as problems with concentration of attention, decision-making and reasoning in complex situations. However, general intellectual abilities and higher order cognitive skills are intact. Directions for future research are outlined.

KEY WORDS

chronic fatigue syndrome; multiple sclerosis; myasthenia gravis 


\section{BACKGROUND}

Symptoms, causes and methods of fighting fatigue were described even in the oldest literary works. Classical and contemporary scientific literature, e.g. in the field of physiology, medicine, psychology and sociology (Burnham, 1908; Jodzio \& Treder, 2014; Joteyko, 1932), present the multidimensional nature of fatigue, and thus fatigue appears in various contexts: biological, psychological, and social. An at-
Natalia Treder, Krzysztof Jodzio tempt at simple and arbitrary division of objective and subjective fatigue symptoms, its physiological and psychological correlates, would be difficult, if not artificial. It would question a strict correlation between somatic and psychological symptoms of fatigue, or, more broadly speaking, its 'bodily' and 'spiritual' elements, which are interwoven in human behaviour. For example, mental effort while solving problems is often accompanied by increase in tension of skeletal muscles, which puts a strain on physiological processes and reduces their compensative function. And muscle fatigue resulting from movement, i.e. physical activity, leads to a subjective assessment of one's results and gives a sense of justifiability of the undertaken actions. It is therefore well-grounded that the issue of fatigue has been given a significant place in various fields of psychology, such as health psychology, clinical psychology, neuropsychology, psychophysiology, occupational psychology, personality psychology, sports psychology, and developmental psychology.

Fatigue does not need to be an unpleasant and undesirable state. It serves as a signal and has an important biological role: it is a detector of threat to the body which needs regeneration and rest. The biological role of fatigue was described by Józefa Joteyko (1932), who argued that fatigue in humans is characterized by a very significant and specific feature which she called 'weariness' or 'weakness'. Thus she emphasised the psycho-physiological aspect of fatigue. Today, fatigue is viewed as a process which prevents us from energetic exhaustion of our bodies (including the brain), and not necessarily a symptom of weariness (cf. Chojnacka-Szawłowska, 2009; Marek, 2000).

A significant and multi-directional intensification of research in the last two decades aiming at explaining the complex nature of fatigue results from a dynamic socio-civilizational development, and hence changing conditions of life. Against a backdrop of unquestionable civilizational advances, new threats emerge. The process in question is a long-term one as fatigue has been named a 'problem of modern civilization' as early as in the 1970s (Jethon, 1977). More and more 'fatigued' society is a real and intensifying trend, which needs to be treated as a serious clinical challenge. Early recognition of pathological symp- toms, i.e. long-lasting and destructive fatigue, is of vital practical importance, e.g. in prophylactics and therapy. Multi-aspect evaluation of fatigue which includes its health-related and psychological aspects facilitates differential diagnosis of somatic illnesses, especially neuromuscular diseases.

Clinicians' dissertations about fatigue focus on its three aspects, or detailed issues. The first and most important aspect is to determine when fatigue is only a harmless, though unpleasant condition resulting from a natural defensive mechanism of the body, and when it becomes a pathological state. It is helpful to measure the period of symptoms' occurrence. Differential diagnostics and symptom detection of pathological fatigue is based on the assumption that it is chronic, i.e. it does not subside after sleep, relaxation or rest. According to some authors cited by Chojnacka-Szawłowska (2009, p. 77), fatigue can be treated as a chronic condition if it persists for longer than a month. More rigorous criteria demand at least a 6-month period of fatigue, as in the chronic fatigue syndrome (CFS) presented below. Apart from the chronic nature of pathological fatigue, it is also unnaturally intense, which hinders everyday life.

The remaining two aspects of fatigue which arouse controversy are its clinical structure and aetiology. Pathological fatigue is often defined as a relatively simple phenomenon, i.e. a single-symptom condition, or (more often) as a multi-symptom syndrome, wherein a sense of psycho-physical weariness is accompanied by other disorders, such as in the case of CFS (cf. below). Fatigue as a single symptom or syndrome is mentioned in descriptions of many (etiologically diverse) conditions. Among them, one can find anaemia, auto-immune illnesses (especially thyroiditis, myasthenia gravis, systemic lupus erythematosus), rheumatic diseases (e.g. fibromyalgia), depression, somatisation disorder, chronic infections, cancer (including thyroid cancer), sleep disorders, post-traumatic neurological syndromes and demyelinization such as multiple sclerosis (Brola, Ziomek \& Czernicki, 2007).

Aetiopathogenesis of fatigue can be perceived from a different angle as well - by reversing the cause-and-effect relation. It relates to the pathogenic role of fatigue, which serves as a source of other disorders (Joteyko, 1932). In other words, fatigue paired with a somatic condition points to a question: what is the cause, and what is merely an effect? All the above-mentioned ambiguities have made it impossible for specialists to agree whether fatigue, especially CFS, is indeed a separate diagnostic category, i.e. a primary disorder, which needs to be differentiated from a state of secondary exhaustion resulting from somatic, neural, and mental conditions (Kulik, 2010).

(Neuro)psychological correlates of fatigue in somatic patients is a less researched issue than a well-documented relation between fatigue and psychiatric 
disorders, such as neurasthenia or depression. Therefore, this article discusses the spread and symptoms of fatigue in chronic fatigue syndrome, as well as two neurological illnesses, namely multiple sclerosis and myasthenia gravis, whose key symptom is fatigue. The final diagnosis of these diseases is always a dramatic moment in the life of a patient who is facing painful, persistent and often inauspicious symptoms.

\section{CHRONIC FATIGUE SYNDROME}

The name and diagnostic criteria for chronic fatigue syndrome (CFS) was proposed in the 1980s by American researchers from the Center for Behavior Control in Atlanta (Białyszewski, 1993). They described CFS as a condition with an unknown aetiology, whose main symptom is a long-lasting, minimum 6-month intense sense of fatigue. Along with other non-specific symptoms, it upsets physical and mental functioning of an individual. Both the definition of fatigue and diagnostic criteria were modified many times later on. In 1991, Oxford Criteria for CFS (Sharpe et al., 1991) were established - it became a disorder of unknown aetiology or post-infectious fatigue syndrome. Some time later, the diagnostics was further specified: the patient had to be assessed in terms of major criteria and additional criteria (Białyszewski, 1993; Fukuda et al., 1994). For a CFS diagnosis, the patient should meet both major criteria and at least 4 additional criteria. Namely, the patient has been experiencing persistent or relapsing chronic fatigue for at least 6 months, which does not pass after rest, does not result from physical activity and has not occurred in the past, and significantly limits the patient's social, professional and personal activity. Other somatic and mental illnesses must be ruled out, such as untreated hypothyroidism, hepatitis B and C, narcolepsy, psychosis (especially depression), eating disorders or addiction to psychoactive substances/medical drugs, which result in fatigue. The sense of fatigue is accompanied by symptoms described as additional criteria: self-reported impairment in short-term memory or concentration, sore throat, muscle pain, joint pain, swollen lymph nodes, sleep disorders. These diagnostic criteria for CFS are currently used by many researchers.

In 2007, The National Institute for Health and Clinical Excellence used these criteria (Fukuda et al., 1994) to publish interdisciplinary guidelines which aimed at facilitating diagnostics of fatigue. They recommended detailed biochemical blood and urine analyses and tests for infections (e.g. borreliosis, hepatitis, HIV, mononucleosis, toxoplasmosis, cytomegaly). Although chronic fatigue - as a separate nosologic category - has not been included in the ICD 10 classification and DSM-IV, in 1993 the World Health Organization put CFS on the list of diseases of civili- sation (see: Ogińska-Bulik, 2010). The list of nervous system diseases in ICD 10 was expanded with a new code (G93.3), which signifies post-viral fatigue syndrome (Bailly, 2002; Jason, Fenell \& Taylor, 2003). It doesn't change the fact that diagnosis, and even the existence of chronic fatigue as a separate nosologic-medical unit, still arouses controversy. Sceptics argue that clinical conclusions are based mainly on subjective feelings of patients and require exclusion of other chronic diseases. The diagnostic decision of clinicians is therefore burdened with some incertitude. Therefore, a CFS diagnosis should be preceded by a detailed assessment of the patient's mental state, optimally by a (neuro)psychologist and a psychiatrist. Neurotic and anxiety-depression symptoms, auto destructive thoughts, chronic pain syndromes, many viral, allergic and immunological diseases are of great differential significance.

It is estimated that $93 \%$ of individuals with CFS experience muscle weakness; moreover, patients often report problems with the osteoarticular system, such as joint pain, stiffness in the joints, paraesthesia and other somatic symptoms, such as sore throat, digestion disorders, swollen lymph nodes, and problems with breathing. Additionally, hypersensitivity to light, smell and taste might occur. Chronic fatigue is often accompanied by headaches, chest and stomach aches as well as sleep disorders. Fatigue significantly reduces everyday activity. Patients lack energy to work, some of them even resign; they need a lot of time to regenerate. Cognitive dysfunctions are also common, such as problems with concentration, decision-making and higher reasoning in complex situations. These are further accompanied by emotional and motivational problems, such as apathy, nervousness and lack of enthusiasm (King \& Jason, 2005; Kulik, 2010; Tiersky, Johnson, Lange, Natelson \& DeLuca, 1997).

Although fatigue is a common problem in clinical practice, the CFS is rarely diagnosed, especially in Europe. Naturally, this does not question fatigue as a serious and gradually growing social problem. It is estimated that even one million of Americans and a quarter of a million of the British may suffer from CFS; in Poland, the syndrome is not popularly diagnosed by doctors (Bitner, Klawe, Zalewski \& Tafil-Klawe, 2013). Symptoms of chronic fatigue are more likely to be observed in women than in men, and amongst young people, aged between 20 and 40 (Nisenbaum, Reyes, Unger \& Reeves, 2004).

A prevailing belief is that the aetiology of CFS is complex. On one hand, neurobiological factors are mentioned, such as incorrect transmission of impulses through nerve fibres (white matter), or neuroendocrinological dysfunctions resulting from incorrect functioning of the hypothalamus-pituitary gland-adrenal cortex axis, immunological insufficiency or infectious processes (Komaroff \& Cho, 2011; Tiersky et al., 
Natalia Treder, Krzysztof Jodzio
1997). On the other hand, the role of intense stress is emphasized. Some research shows that patients with CFS experience many stressful events; therefore they find it hard to establish strong social relations (Hyland, 2001).

The unclear aetiology and non-specific clinical image of chronic fatigue make its treatment difficult. Psychological care, especially psychological education and psychotherapy, are vital. Powell, Bentall, Nye and Edwards (2001) showed that psychotherapy resulted in better results than pharmacological treatment and relaxation therapy. Effectiveness of behavioural-cognitive therapy was confirmed in $70 \%$ patients with CFS. Physical activity and change of lifestyle are also recommended, especially a healthy diet and sleep hygiene.

\section{SYMPTOMS OF FATIGUE IN MULTIPLE SCLEROSIS PATIENTS}

The feeling of fatigue is one of the most common problems reported by $40-90 \%$ of patients with multiple sclerosis (MS), and every second patient finds this symptom unbearable. Fatigue hinders everyday activity and family life, thus lowering the overall quality of life (Krupp, Alvarez, LaRocca \& Scheinberg, 1988; Łabuz-Roszak et al., 2009).

Fatigue accompanies many neurological diseases, but in patients with MS it is exceptionally intense and nagging. Moreover, it serves as an important disability predicator, regardless of results of objective neurological tests, e.g. motor deficit assessment. A key element is to distinguish 'natural' (healthy) fatigue from pathologically increased tiredness. In both cases, fatigue grows stronger as a result of stress, mental or physical effort. However, a specific feature of tiredness in MS patients is the speed at which the feeling of fatigue appears. The feeling of exhaustion appears even after slight psycho-physical activity and/or results from heat. What is more, it intensifies in the morning, and rest and sleep do not bring relief. The nature - or more generally speaking, heterogeneity of the disease - is very important. Fatigue in MS patients is usually either of primary or secondary progressive or relapsing-remitting nature; it is also suffered by patients with cerebellar, pyramidal symptoms, or sphincter dysfunctions. Women are more prone to this problem than men (Brola \& Fudala, 2011).

Patients usually complain about diminished attention span, drowsiness during the day, tiredness as well as lack of energy to take up activities that did not use to cause any problems. All these symptoms hinder execution of social and family duties. They resemble depression, which is another challenge faced by MS patients. However, fatigue in patients suffering only from depression has a predominantly mental nature, which hinders execution of diagnostic tasks, lowers motivation and interest. As for fatigue in MS patients, it is also a physical or somatic affliction. Symptoms of depression, on the other hand, are depressive mood and avoidance of social contacts. Despite the unclear cause-and-effect relation, many clinicians believe that depression and fatigue are two tightly connected symptoms of MS. Depression, which becomes most intense in patients who constantly feel fatigue, correlates with its intensity, which seems to suggest a shared pathomechanism of the symptoms (Chojnacka-Szawłowska, 2009).

Pathogenesis of fatigue in MS patients is not entirely clear. It is difficult to determine which mechanism of the nervous system - central or peripheral - plays a more significant role in the development of this symptom. Currently, a prevailing belief is that fatigue has a central origin. Dysfunctions of the frontal and parietal lobe, thalamus and basal ganglia are also suspected (cf. Sepulcre et al., 2009; Pellicano et al., 2010). This leads one to believe that fatigue in MS patients is related to impairment of the connectivity in cortico-subcortical circuits. Before that, Tiersky et al. (1997) speculated about the relation between chronic fatigue and incorrect state of the white matter in the cerebrum, whose atrophy, as we know, is the foundation of MS. Research suggests that there is a strong relation between fatigue and incorrect immunological reactions. Not surprisingly, fatigue is intensified when a disease or infection exacerbates. Besides, post-mortems have shown damage to the hypothalamus-pituitary gland-adrenal cortex axis in many MS patients (Palasik, 2009). Most likely, the aetiology of fatigue is multi-factor, and fatigue itself may result from a combination of primary and secondary factors.

The complex and unclear mechanism of fatigue in MS patients hinders treatment. Apart from pharmacotherapy, rehabilitation and physical activity (suited to patient abilities) are recommended. It should also be noted that physical activity has a beneficial impact and helps reduce symptoms of fatigue by as much as $40-50 \%$. Relaxation techniques and education programmes are very helpful for both the patient and their family/caretakers, who are encouraged to actively participate in the treatment and rehabilitation process.

\section{SYMPTOMS OF FATIGUE IN MYASTHENIA GRAVIS PATIENTS}

Myasthenia gravis (MG) is a pathological neuromuscular, autoimmune disease resulting in pathological muscle tiredness. Symptoms usually affect eye and facial muscles, limbs, and muscles with bulbar nerves. In Poland, there are approximately 5,000 people with MG, mostly young women (aged 18-30), although there are cases of late myasthenia with onset 
in patients' 50s (equally common in men and women) (Emeryk-Szajewska \& Strugalska-Cynowska, 2005; Strugalska-Cynowska, 2008). Fatigue in MG is disproportionate to physical activity; furthermore, it sometimes leads to temporary muscle paralysis, i.e. total exhaustion of muscles.

Diagnosis of this disease is not easy due to varied, individual symptomatology, which sometimes gets confused with nervous disorders, conversive symptoms (formerly known as hysteria), multiple sclerosis, myopathy and hyperthyroidism. The disease progresses rapidly, resembling e.g. cerebral stroke, or is similar to chronic fatigue syndrome. The first symptom of the disease in $15 \%$ of cases is weakness and fatigability of limb muscles. Patients report experiencing an increased sense of fatigue (i.e., exhaustion and tiredness) with levels peaking at the end of the day (Bilińska \& Nyka, 2011). Myasthenia gravis patients report symptoms of both mental and physical fatigue. They also report that fatigue significantly limits their physical and psycho-social activity. Moreover, women with MG are more prone to fatigue (Grohar-Murray, Becker, Reilly \& Ricci, 1998).

Interestingly, there is a relationship between development of mental fatigue and reduced cognitive performance, described by Paul, Cohen \& Gilchrist (2002). All patients made a subjective assessment of fatigue before and after the cognitive functions test, both of mental and physical fatigue. It was observed that there was a significant correlation between subjective feeling of fatigue and cognitive functions in terms of information processing speed, verbal fluency, aural-verbal learning and visual-spatial memory. This correlation turned out to be typical only for MG patients, not for healthy individuals. Although patients claimed that physical fatigue impacted their cognitive abilities, the correlation was observed only for mental fatigue. The cited authors (ibid.) also proved a significant increase in the subjective fatigue after completing numerous neuropsychological tests.

However, the prevailing view states that this cognitive deficit is of secondary nature, e.g. it results from hypoxia during sleep or pharmacological treatments, e.g. with corticosteroid or anti-depressants (Keesey, 1999). Regardless of all doubts, mental fatigue is an important symptom of MG, one that impairs many aspects of patients' everyday lives. Persistent fatigue, muscle tiredness, chronic nature of the illness and ill-boding prognosis make MG a source of intense stress for patients and their families, whose quality of life becomes significantly lowered.

\section{CONCLUSIONS}

Fatigue is a paradoxical sensation, since its mere existence arouses some controversy - unlike attempts at clinical interpretation, which are the polar opposite. On one hand, fatigue is defined as a relatively simple symptom which accompanies many conditions met in neurological, psychiatric and internal medicine practice. On the other hand, fatigue may be a separate nosological and diagnostic unit, i.e. an isolated syndrome with non-specific, somewhat primary aetiology. In other words, researchers try to determine whether fatigue is a psycho-somatic phenomenon with a homogenous character, single-symptom and non-specific, or if it is a more heterogeneous phenomenon, multi-symptom (clinically complex) and specific. Psychologists cannot ignore individual differences in ways of experiencing and fighting fatigue. Quite probably, psychological research of fatigue will facilitate determination of its subtypes.

Furthermore, differential diagnostics is of utmost importance, i.e. the need to determine clear criteria to detect fatigue as a natural psycho-physiological state versus pathological phenomenon. It seems that quantitative parameters, which so far have been mostly taken into account, e.g. intensity and period of fatigue, have a limited value in differential diagnostics. Instead, more qualitative tools should be developed, or at least a complex and integrated research approach needs to be adapted, whose popularization would facilitate closer cooperation between various specialists, such as psychologists, doctors and neurobiologists. Results of this cooperation could aid developing practical strategies for coping and handling chronic fatigue common in patients with multiple sclerosis or myasthenia gravis, rather than providing detailed classification of the existing psychological typologies or clinical classifications. These diseases have a highly destructive impact not only on the system and health of patients but also on their everyday life, overall wellbeing and family life.

\section{References}

Bailly, L. (2002). Chronic fatigue syndrome or neurasthenia? British Journal of Psychiatry, 181, 350-351.

Białyszewski, A. (1993). Zespół przewlekłego zmęczenia [The chronic fatigue syndrome]. Psychiatria Polska, 27, 601-612.

Bilińska, M., \& Nyka, W. (2011). Trudności diagnostyczne w przypadku miastenii [Diagnostic difficulties in myasthenia gravis]. Polski Merkuriusz Lekarski, 30, 277-282.

Bitner, A., Klawe, J. J., Zalewski, P., \& Tafil-Klawe, M. (2013). Etiologia zespołu przewlekłego zmęczenia $z$ uwzględnieniem zaburzeń funkcjonowania autonomicznego układu nerwowego [Etiology of chronic fatigue syndrome with reference to the autonomic nervous system dysfunction]. Problemy Higieny i Epidemiologii, 94, 6-8.

Brola, W., Ziomek, M., \& Czernicki, J. (2007). Zespół zmęczenia w przewlekłych chorobach neurologicz- 
nych [Fatigue syndrome in chronic neurological disorders]. Neurologia i Neurochirurgia Polska, 41, 340-349.

Brola, W., \& Fudala, M. (2011). Aktualne poglądy na patogenezę i leczenie zespołu zmęczenia w stwardnieniu rozsianym [Current opinions of pathogenesis and treatment of fatigue syndrome in multiple sclerosis]. Aktualności Neurologiczne, 11, 23-28.

Burnham, W. H. (1908). The problem of fatigue. The American Journal of Psychology, 19, 385-399.

Natalia Treder, Krzysztof Jodzio

Chojnacka-Szawłowska, G. (2009). Zmęczenie a zdrowie i choroba. Perspektywa psychologiczna [Fatigue, health and disease. Psychological perspective]. Kraków: Oficyna Wydawnicza „Impuls”.

Emeryk-Szajewska, B., \& Strugalska-Cynowska, H. M. (2005). Miastenia i zespoły miasteniczne [Myasthenia and myasthenic syndromes]. In: I. Haussmanowa-Petrusewicz (ed.). Choroby nerwowo-mięśniowe [Neuromuscular Diseases]. Lublin: Wydawnictwo Czelej.

Fukuda, K., Straus, S. E., Hickie, I., Sharpe, M. C., Dobbins, J. G., \& Komaroff, A. (1994). The chronic fatigue syndrome: a comprehensive approach to its definition and study. Annals of Internal Medicine, 121, 953-959.

Grohar-Murray, M. E., Becker, A. B., Reilly, S., \& Ricci, M. (1998). Self-care actions to manage fatigue among myasthenia gravis patients. Journal of Neuroscience Nursing, 33, 191-199.

Hyland, M. E. (2001). Extended network learning error: a new way of conceptualising chronic fatigue syndrome. Psychology and Health, 16, 273-287.

Jason, L., Fenell, D., \& Taylor, R. (eds.) (2003). Handbook of chronic fatigue syndrome. New York: Wiley. Jethon, Z. (ed.) (1977). Zmęczenie jako problem wspótczesnej cywilizacji [Fatigue as a problem of contemporary civilization]. Warszawa: Państwowy Zakład Wydawnictw Lekarskich.

Jodzio, K., \& Treder, N. (2014). Poglądy na przewlekłe zmęczenie i jego wpływ na zachowanie w XIX wieku i na początku XX wieku [Ideas about chronic fatigue and its impact on behaviour in nineteenth century and at the beginning of the twentieth century]. Psychiatria i Psychoterapia, 10, 11-22.

Joteyko, J. (1932). Znużenie [La Fatigue]. Warszawa: Wydanie z Zasiłku Funduszu Kultury Narodowej. Skład Główny: Książnica - Atlas.

Keesey, J. C. (1999). Does myasthenia gravis affect the brain? Journal of the Neurological Sciences, 170, 77-89.

King, C., \& Jason, L. A. (2005). Improving the diagnostic criteria and procedures for chronic fatigue syndrome. Biological Psychology, 68, 87-106.

Komaroff, A. L., \& Cho, T. A. (2011). Role of infection and neurologic dysfunction in chronic fatigue syndrome. Seminars in Neurology, 31, 325-37.
Krupp, L. B., Alvarez, L. A., LaRocca, N. G., \& Scheinberg, L. C. (1988). Fatigue in multiple sclerosis. Archives of Neurology, 45, 435-437.

Kulik, A. (2010). Zmęczenie przewlekte u nastolatków. Charakterystyka psychologiczna [Chronic fatigue in teenagers. Psychological characteristics]. Lublin: Wydawnictwo KUL.

Łabuz-Roszak, B., Pierzchała, K., Kumor, K., Wyrozumska, K., Baran, A., Werner, A., Bąk, E., \& Jaźwiecka, M. (2009). Ocena częstości występowania zespołu zmęczenia u chorych na stwardnienie rozsiane [Evaluation of frequency of fatigue syndrome in patients with multiple sclerosis]. Wiadomości Lekarskie, 62, 99-103.

Marek, T. (2000). Stres i zmęczenie psychiczne w procesie pracy [Mental stress and fatigue at work]. Czasopismo Psychologiczne, 6, 35-40.

Nisenbaum, R., Reyes, M., Unger, E. R., \& Reeves, W.C. (2004). Factor analysis of symptoms among subjects with unexplained chronic fatigue: what can we learn about chronic fatigue syndrome? Journal of Psychosomatic Research, 56, 171-178.

Ogińska-Bulik, N. (2010). Uzależnienie od czynności. Mit czy rzeczywistość? [Behavioral dependence: myth or fact?]. Warszawa: Wydawnictwo Difin.

Palasik, W. (2009). Zespół zmęczeniowy, depresja i zaburzenia funkcji poznawczych - podstawowe czynniki zmieniające jakość życia chorych ze stwardnieniem rozsianym [Fatigue syndrome, depression and cognitive dysfunction - basic factors changing quality of life of patients with multiple sclerosis]. Aktualności Neurologiczne, 9, 267-271.

Paul, R. H., Cohen, R. A., \& Gilchrist, J. M. (2002). Ratings of subjective mental fatigue relate to cognitive performance in patients with myasthenia gravis. Journal of Clinical Neuroscience, 9, 243-246.

Pellicano, C., Gallo, A., Li, X., Ikonomidou, V. N., Evangelou, I. E., Ohayon, J. M., Stern, S. K., Ehrmantraut, M., Cantor, F., \& McFarland, H. F (2010). Relationship of cortical atrophy to fatigue in patients with multiple sclerosis. Archives of Neurology, 67, 447-453.

Powell, P., Bentall, R. P., Nye, F. J., \& Edwards, R. H. (2001). Randomised controlled trial of patient education to encourage graded exercise in chronic fatigue syndrome. British Medical Journal, 322, 387-390.

Sepulcre, J., Masdeu, J. C., Goñi, J., Arrondo, G., Vélez de Mendizábal, N., \& Bejarano, B. (2009). Fatigue in multiple sclerosis is associated with the disruption of frontal and parietal pathways. Multiple Sclerosis Journal, 15, 337-344.

Sharpe, M. C., Archard, L. C., Banatvala, J. E., Borysiewicz, K. L., Clare, W. A., David, A., Edwards, R. H., Hawton, K. E., Lambert, H. P., \& Lane, R. L. (1991). A report - chronic fatigue syndrome: guidelines for research. Journal of the Royal Society of Medicine, 84, 118-121. 
Sitek, E. J., Sławek, J., \& Wieczorek, D. (2009). Funkcjonowanie poznawcze w miastenii [Cognitive functioning in myasthenia]. Postępy Psychiatrii i Neurologii, 18, 387-391.

Strugalska-Cynowska, M. H. (2008). Obraz kliniczny i diagnostyka immunologiczna miastenii i zespołu Lamberta-Eatona [Myasthenia gravis and Lambert-Eaton myasthenic syndrome (clinical and immunological advances, signifity of autoantibodies for diagnosis and treatment)]. Polski Przegląd Neurologiczny, 4, 75-76.

Tiersky, L. A., Johnson, S. K., Lange, G., Natelson, B. H., Chronic fatigue \& DeLuca, J. (1997). Neuropsychology of chronic fatigue syndrome: a critical review. Journal of Clinical and Experimental Neuropsychology, 19, 560-586. 